\title{
Negative-to-Positive Lymph Node Ratio as an Independent Prognostic Factor for Gastric Adenocarcinoma
}

\author{
Huseyin Alakus ${ }^{1}$, Mustafa Kaya ${ }^{2}$, Murat Can Mollaoglu ${ }^{3}$, Mustafa Göksu ${ }^{4}$, Hatice Ozer ${ }^{5}$ and Kursat Karadayi ${ }^{6}$ \\ ${ }^{1}$ Department of Surgical Oncology, Faculty of Medicine, Adiyaman University, Turkey \\ ${ }^{2}$ Department of Surgical Oncology, Dr. Ersin Aslan Education and Research Hospital, Gaziantep, Turkey \\ ${ }^{3}$ Department of Surgical Oncology, Faculty of Medicine, Cumhuriyet University, Sivas, Turkey \\ ${ }^{4}$ Department of General Surgery, Faculty of Medicine, Adiyaman University, Turkey \\ ${ }^{5}$ Department of Pathology, Faculty of Medicine, Cumhuriyet University, Sivas, Turkey \\ ${ }^{6}$ Department of Surgical Oncology, Faculty of Medicine, Cumhuriyet University, Sivas, Turkey
}

\begin{abstract}
Objective: To investigate the association between the ratio of negative/positive lymph nodes (RNP) and other clinic pathological parameters.

Study Design: Descriptive study.

Place and Duration of Study: Faculty of Medicine, Cumhuriyet University, Sivas, Turkey, from February 2008 to December 2019.

Methodology: Consecutive 119 patients with gastric adenocarcinoma, who underwent gastrectomy and D2 lymph node dissection, were included. RNP, other clinicopathological parameters such as tumour grade, type and lymphovascular invasion (LVI) were analysed, as their prognostic impact was investigated.

Results: RNP was an independent prognostic factor for overall survival $(p=0.003$ ) and was significantly associated with poor survival ( $p<001$ ). Advanced pathologic T and $\mathrm{N}$ stage, presence of perineural invasion (PNI), presence of LVI, high tumour grade, and diffuse-type as per Louren's classification, and the number of the negative lymph nodes were also significantly associated with poor survival (all $p<0.05)$. Although pathologic N stage $(p<0.01)$, PNI $(p<0.01)$, LVI $(p<0.01)$, tumour type as per Louren's classification $(p<0.01)$, tumour grade $(p<0.01)$ and the number of negative lymph nodes $(p<0.01)$ were significantly associated with overall survival in univariate analyses; only gender $(p=0.025)$, gastrectomy type $(p=0.037)$, PNI $(p=0.028)$, tumour type $(p=$ $0.006)$, and number of negative lymph nodes $(p=0.003)$ were meaningfully associated with survival in a multivariate analysis.

Conclusion: The ratio of negative/positive lymph nodes can be used as an independent prognostic marker in patients with gastric cancer, who undergo curative resection, as an alternative prognostic marker to the pathologic $\mathrm{N}$ stage.
\end{abstract}

Key Words: Stomach neoplasms, Lymph node ratio, Prognosis, Gastrectomy, Lymph nodes.

How to cite this article: Alakus H, Kaya M, Mollaoglu MC, Göksu M, Ozer H, Karadayi K. Negative-to-Positive Lymph Node Ratio as an Independent Prognostic Factor for Gastric Adenocarcinoma. J Coll Physicians Surg Pak 2021; 31(07):805-810.

\section{INTRODUCTION}

Gastric cancer remains the sixth-leading cancer globally, and the fifth major cause of death, associated with cancer for both males and females. ${ }^{1,2}$ Lymph node involvement is one of the most significant prognostic parameters for gastric adenocarcinoma. ${ }^{3}$ Staging is based on the correct assessment of lymph node status to predict reliable survival. ${ }^{4}$

Correspondence to: Dr. Mustafa Göksu, Department of General Surgery, Faculty of Medicine, Adiyaman University Training and Research Hospital, Adiyaman, Turkey E-mail: drmustafagoksu@gmail.com

Received: February 04, 2021; Revised: May 02, 2021; Accepted: June 21, 2021

DOI: https://doi.org/10.29271/jcpsp.2021.07.805
In the American Joint Committee on Cancer's (AJCC) 7th and 8th editions, a count of metastatic lymph nodes determined pathologic N-stage. ${ }^{5}$ However, whether this system is effective is controversial, as it is dependent on the count of positive lymph nodes; yet some authors suggest its prognostic ability may be limited and/or may not be applicable to all cases of gastric adenocarcinoma, especially in cases with insufficient lymph node dissection. ${ }^{6-8}$

Recently, the ratio of negative/positive lymph nodes (RNP) was proposed as an alternative prognostic marker in gastric cancer patients. ${ }^{3,4,7,8}$

The aim of this study was to search for the prognostic significance of RNP and its association to other traditional prognostic markers in patients with gastric adenocarcinoma, who had gastrectomy and D2 lymph node dissection. 
Table I: Clinicopathologic characteristics of the study group.

\begin{tabular}{|c|c|c|c|c|c|}
\hline \multirow{2}{*}{ Variable } & \multirow{2}{*}{$n(\%)$} & \multicolumn{3}{|c|}{$\mathbf{R}_{\mathrm{NP}}$} & \multirow{2}{*}{ p-value } \\
\hline & & $\mathbf{R}_{\mathrm{NP}} \mathbf{1}$ & $\mathbf{R}_{\mathrm{NP}} \mathbf{2}$ & $\mathbf{R}_{\mathrm{NP}} \mathbf{3}$ & \\
\hline $\begin{array}{l}\text { Age (year) } \\
\leq 65 \\
>65\end{array}$ & $\begin{array}{l}50(42.0) \\
69(58.0)\end{array}$ & $\begin{array}{l}12(40.0) \\
18(60.0)\end{array}$ & $\begin{array}{l}14(37.8) \\
23(62.2)\end{array}$ & $\begin{array}{l}24(46.2) \\
28(53.8)\end{array}$ & 0.712 \\
\hline $\begin{array}{l}\text { Gender } \\
\text { Female } \\
\text { Male }\end{array}$ & $\begin{array}{l}22(18.5) \\
97(81.5)\end{array}$ & $\begin{array}{c}6(20.0) \\
24(80.0)\end{array}$ & $\begin{array}{c}6(16.2) \\
31(83.8)\end{array}$ & $\begin{array}{l}10(19.2) \\
42(80.8)\end{array}$ & 0.909 \\
\hline $\begin{array}{l}\text { Gastrectomy } \\
\text { Total } \\
\text { Distal }\end{array}$ & $\begin{array}{l}77(64.7) \\
42(35.3)\end{array}$ & $\begin{array}{l}19(63.3) \\
11(36.7)\end{array}$ & $\begin{array}{l}25(67.6) \\
12(32.4)\end{array}$ & $\begin{array}{l}33(63.5) \\
19(36.5)\end{array}$ & 0.908 \\
\hline $\begin{array}{l}\text { Pathologic T stage } \\
\text { T1a } \\
\text { T1b } \\
\text { T2 } \\
\text { T3 } \\
\text { T4a } \\
\text { T4b }\end{array}$ & $\begin{array}{c}1(0.8) \\
4(3.4) \\
7(5.9) \\
31(26.1) \\
60(50.4) \\
16(13.4)\end{array}$ & $\begin{array}{c}- \\
- \\
4(13.3) \\
11(36.7) \\
13(43.3) \\
2(6.7)\end{array}$ & $\begin{array}{c}- \\
3(8.1) \\
2(5.4) \\
10(27.0) \\
16(43.2) \\
6(16.2)\end{array}$ & $\begin{array}{c}1(1.9) \\
1(1.9) \\
1(1.9) \\
10(19.2) \\
31(59.6) \\
8(15.4)\end{array}$ & 0.128 \\
\hline $\begin{array}{l}\text { Pathologic N stage } \\
\text { N1 } \\
\text { N2 } \\
\text { N3a } \\
\text { N3b }\end{array}$ & $\begin{array}{l}33(27.7) \\
33(27.7) \\
31(26.1) \\
22(18.5)\end{array}$ & $\begin{array}{c}20(66.7) \\
7(23.3) \\
3(10.0) \\
- \\
\end{array}$ & $\begin{array}{c}9(24.3) \\
18(48.6) \\
10(27.0) \\
\quad-\end{array}$ & $\begin{array}{c}4(7.7) \\
8(15.4) \\
18(34.6) \\
22(42.3)\end{array}$ & $<0.001$ \\
\hline $\begin{array}{l}\text { Tumour location } \\
\text { Upper third } \\
\text { Middle third } \\
\text { Lower third }\end{array}$ & $\begin{array}{l}31(26.1) \\
37(31.1) \\
51(42.9)\end{array}$ & $\begin{array}{c}9(30.0) \\
8(26.7) \\
13(43.3) \\
\end{array}$ & $\begin{array}{l}13(35.1) \\
11(29.7) \\
13(35.1)\end{array}$ & $\begin{array}{l}9(17.3) \\
18(34.6) \\
25(48.1)\end{array}$ & 0.387 \\
\hline $\begin{array}{l}\text { Tumour size } \\
\leq 4 \mathrm{~cm} \\
>4 \mathrm{~cm}\end{array}$ & $\begin{array}{l}42(35.3) \\
77(64.7) \\
\end{array}$ & $\begin{array}{l}12(40.0) \\
18(60.0) \\
\end{array}$ & $\begin{array}{l}14(37.8) \\
23(62.2) \\
\end{array}$ & $\begin{array}{l}16(30.8) \\
36(69.2) \\
\end{array}$ & 0.650 \\
\hline $\begin{array}{l}\text { Perineural invasion } \\
\text { Absent } \\
\text { Present }\end{array}$ & $\begin{array}{l}37(31.1) \\
82(68.9)\end{array}$ & $\begin{array}{l}22(73.3) \\
8(26.7)\end{array}$ & $\begin{array}{c}9(24.3) \\
28(75.7) \\
\end{array}$ & $\begin{array}{c}6(11.5) \\
46(88.5)\end{array}$ & $<0.001$ \\
\hline $\begin{array}{l}\text { Lymphovascular invasion } \\
\text { Absent } \\
\text { Present }\end{array}$ & $\begin{array}{l}39(32.8) \\
80(67.2)\end{array}$ & $\begin{array}{l}18(60.0) \\
12(40.0)\end{array}$ & $\begin{array}{c}9(24.3) \\
28(75.7)\end{array}$ & $\begin{array}{l}12(23.1) \\
40(76.9)\end{array}$ & 0.001 \\
\hline $\begin{array}{l}\text { Tumour type per lauren's classification } \\
\text { Intestinal type } \\
\text { Diffuse type }\end{array}$ & $57(47.9 \%) 62(52.1 \%)$ & $\begin{array}{c}27(90.0) \\
3(10.0)\end{array}$ & $\begin{array}{l}18(48.6) \\
19(51.4)\end{array}$ & $\begin{array}{l}12(23.1) \\
40(76.9)\end{array}$ & $<0.001$ \\
\hline $\begin{array}{l}\text { Tumour grade } \\
\text { Low } \\
\text { Intermediate } \\
\text { High }\end{array}$ & $\begin{array}{l}26(21.8) \\
42(35.3) \\
51(42.9)\end{array}$ & $\begin{array}{c}14(46.7) \\
11(36.7) \\
5(16.7)\end{array}$ & $\begin{array}{c}9(24.3) \\
17(45.9) \\
11(29.7)\end{array}$ & $\begin{array}{c}3(5.8) \\
14(26.9) \\
35(67.3)\end{array}$ & $<0.001$ \\
\hline $\begin{array}{l}\text { LNs } \\
>15 \\
0-14\end{array}$ & $\begin{array}{l}52(43.7) \\
67(56.3)\end{array}$ & $\begin{array}{c}8(26.7) \\
22(73.3)\end{array}$ & $\begin{array}{l}17(45.9) \\
20(54.1)\end{array}$ & $\begin{array}{l}27(51.9) \\
25(48.1)\end{array}$ & 0.080 \\
\hline
\end{tabular}

\section{METHODOLOGY}

Following the approval of the study protocol by the local Ethics Committee, records of 437 consecutive patients with gastrectomy, due to gastric cancer between February 2008 and December 2019 at Faculty of Medicine, Cumhuriyet University, Sivas, Turkey, were screened and evaluated. Histopathological tumour types, other than adenocarcinoma (gastric lymphoma, gastric neuroendocrine tumour, etc.); patients with adenocarcinoma who did not have lymph node metas- tasis; stage 4 disease; patients receiving neoadjuvant chemotherapy; history of stomach surgery for any cause; an otherwise known malignancy; the presence of a positive surgery border as a result of a pathology specimen; D1 lymph node dissection; patients with a Siewert type 3 tumour of gastroesophageal component, died in the 30 postoperative days, were not included in the study.

An experienced oncologic surgeon performed all procedures. That study consisted of 119 patients, who were included in the criteria.

Table II: Results of the univariate and multivariate analysis between clinicopathologic parameters and prognosis.

\begin{tabular}{|c|c|c|c|c|c|c|c|}
\hline \multirow{2}{*}{ Variable } & \multirow{2}{*}{$n(\%)$} & \multicolumn{2}{|c|}{ Median Survival } & \multicolumn{2}{|c|}{ Univariate } & \multicolumn{2}{|c|}{ Multivariate } \\
\hline & & Month & p-value & HR (95\%C.I) & p-value & HR (95\%C.I) & p-value \\
\hline
\end{tabular}




\begin{tabular}{|c|c|c|c|c|c|c|c|}
\hline $\begin{array}{l}\text { Age (year) } \\
\leq 65 \\
>65\end{array}$ & $\begin{array}{l}50(42.0) \\
69(58.0)\end{array}$ & $\begin{array}{l}18.1 \\
15\end{array}$ & 0.789 & $0.942(0.607-1.462)$ & 0.791 & & NS \\
\hline $\begin{array}{l}\text { Gender } \\
\text { Female } \\
\text { Male }\end{array}$ & $\begin{array}{l}22(18.5) \\
97(81.5)\end{array}$ & $\begin{array}{l}18 \\
16\end{array}$ & 0.300 & $0.726(0.392-1.344)$ & 0.308 & $0.470(0.243-0.908)$ & 0.025 \\
\hline $\begin{array}{l}\text { Gastrectomy } \\
\text { Total } \\
\text { Distal }\end{array}$ & $\begin{array}{l}77(64.7) \\
42(35.3)\end{array}$ & $\begin{array}{l}17 \\
18\end{array}$ & 0.998 & $0.999(0.639-1.563)$ & 0.998 & $0.588(0.357-0.969)$ & 0.037 \\
\hline $\begin{array}{l}\text { Pathologic T Stage } \\
\text { T1a } \\
\text { T1b } \\
\text { T2 } \\
\text { T3 } \\
\text { T4a } \\
\text { T4b }\end{array}$ & 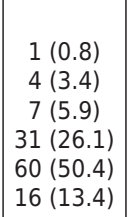 & $\begin{array}{c}29 \\
49 \\
49 \\
27.9 \\
14.9 \\
11\end{array}$ & 0.012 & $\begin{array}{l}0.446(0.058-3.399) \\
0.369(0.105-1.300) \\
0.270(0.089-0.821) \\
0.289(0.139-0.601) \\
0.572(0.316-1.034)\end{array}$ & $\begin{array}{l}\mathbf{0 . 0 2 0} \\
0.436 \\
0.121 \\
\mathbf{0 . 0 2 1} \\
\mathbf{0 . 0 0 1} \\
0.064\end{array}$ & & NS \\
\hline $\begin{array}{l}\text { Pathologic N Stage } \\
\text { N1 } \\
\text { N2 } \\
\text { N3a } \\
\text { N3b }\end{array}$ & $\begin{array}{l}33(27.7) \\
33(27.7) \\
31(26.1) \\
22(18.5)\end{array}$ & $\begin{array}{c}49 \\
15 \\
12 \\
9\end{array}$ & 0.001 & $\left|\begin{array}{c}0.082(0.038-0.176) \\
0.251(0131-0.481) \\
0.598(0.327-1.095)\end{array}\right|$ & $\begin{array}{l}<0.01 \\
<0.01 \\
<0.01 \\
0.096\end{array}$ & $0.303(0.121-0.762)$ & $\begin{array}{l}0.051 \\
\mathbf{0 . 0 1 1}\end{array}$ \\
\hline $\begin{array}{l}\text { Tumour Location } \\
\text { Upper third } \\
\text { Middle third } \\
\text { Lower third }\end{array}$ & $\begin{array}{l}31(26.1) \\
37(31.1) \\
51(42.9)\end{array}$ & $\begin{array}{l}21 \\
20 \\
16\end{array}$ & 0.855 & $\begin{array}{l}0.963(0.564-1.646) \\
1.119(0.672-1.863)\end{array}$ & $\begin{array}{l}0.859 \\
0.891 \\
0.666\end{array}$ & & NS \\
\hline $\begin{array}{l}\text { Tumor size } \\
\leq 4 \mathrm{~cm} \\
>4 \mathrm{~cm}\end{array}$ & $\begin{array}{l}42(35.3) \\
77(64.7)\end{array}$ & $\begin{array}{c}22 \\
14.9 \\
\end{array}$ & 0.180 & $0.734(0.464-1.162)$ & 0.187 & & NS \\
\hline $\begin{array}{l}\text { Perineural Invasion } \\
\text { Absent } \\
\text { Present }\end{array}$ & $\begin{array}{l}37(31.1) \\
82(68.9)\end{array}$ & $\begin{array}{l}78 \\
11\end{array}$ & $<0.001$ & $0.132(0.067-0.258)$ & $<0.01$ & $0.369(0.152-0.898)$ & 0.028 \\
\hline $\begin{array}{l}\text { Lymphovascular Invasion } \\
\text { Absent } \\
\text { Present }\end{array}$ & $\begin{array}{l}39(32.8) \\
80(67.2)\end{array}$ & $\begin{array}{l}49 \\
12\end{array}$ & $<0.001$ & $0.274(0.159-0.474)$ & $<0.01$ & & NS \\
\hline $\begin{array}{l}\text { Tumour type per Lauren's classification } \\
\text { Intestinal type } \\
\text { Diffuse type }\end{array}$ & $\begin{array}{l}57(47.9 \%) \\
62(52.1 \%)\end{array}$ & $\begin{array}{l}40 \\
10\end{array}$ & $<0.001$ & $0.207(0.125-0.474)$ & $<0.01$ & $0.416(0.222-0.780)$ & 0.006 \\
\hline $\begin{array}{l}\text { Tumour Grade } \\
\text { Low } \\
\text { Intermediate } \\
\text { High }\end{array}$ & $\begin{array}{l}26(21.8) \\
42(35.3) \\
51(42.9)\end{array}$ & $\begin{array}{c}66 \\
23 \\
9\end{array}$ & $<0.001$ & $\begin{array}{l}0.150(0.077-0.295) \\
0.377(0.228-0.623)\end{array} \mid$ & $\begin{array}{l}<0.01 \\
<0.01 \\
<0.01\end{array}$ & $0.459(0.221-0.952)$ & $\begin{array}{l}0.101 \\
\mathbf{0 . 0 3 6}\end{array}$ \\
\hline $\begin{array}{l}\text { LNs } \\
>15 \\
0-14\end{array}$ & $\begin{array}{l}52(43.7) \\
67(56.3)\end{array}$ & $\begin{array}{l}12 \\
23\end{array}$ & $<0.001$ & $2.219(1.421-3.464)$ & $<0.01$ & $2.149(1.296-3.565)$ & 0.003 \\
\hline $\begin{array}{l}\mathrm{R}_{\mathrm{NP}} \\
\mathrm{R}_{\mathrm{NP}} 1(>15.00) \\
\mathrm{R}_{\mathrm{NP}} 2(2.01-15.00) \\
\mathrm{R}_{\mathrm{NP}} 3(\leq 2.00)\end{array}$ & $\begin{array}{l}30(25.2) \\
37(31.1) \\
52(43.7)\end{array}$ & $\begin{array}{l}-18.1 \\
8.0\end{array}$ & $<0.001$ & $\begin{array}{l}0.047(0.019-0.116) \\
0.338(0.205-0.558)\end{array}$ & $\begin{array}{l}<0.01 \\
<0.01 \\
<0.01\end{array}$ & $\begin{array}{l}0.172(0.057-0.517) \\
0.443(0.240-0.815)\end{array}$ & $\begin{array}{l}0.003 \\
0.002 \\
0.009\end{array}$ \\
\hline
\end{tabular}

Total gastrectomy was done when the stomach cancer was in the proximal area, or distal gastrectomy when the cancer was in the distal area. In locally advanced cases, neighbouring organs such as the colon, spleen, and pancreas were also resected. The pathologic stage was revised according to the AJCC 8th edition. ${ }^{5}$ Age, gender, type of gastrectomy, pathologic $\mathrm{T}$ and $\mathrm{N}$ stages ( $\mathrm{pT}$ and $\mathrm{pN}$ ), tumour location and, size, grade, histologic type as per Lauren's classification, presence of lymphovascular (LVI) invasion and perineural (PNI) invasion, count of negative-positive lymph nodes, and RNP, were all noted. ${ }^{4}$

Patients were followed until May 2020. They were evaluated by a clinical examination in 3 to 6 months for the first 2 years, then in 6 to 12 months between 2 to 5 years and annually after the fifth year of follow-up. Laboratory screening was performed when necessary. In addition, patients with stages 2 and 3 were assessed by computed tomography (CT) every 6 to 12 months in the first three years and then annually for five years after their operation. Positron emission tomography (PET) was also used in case of clinical need. Data analyses were conducted using the latest version of IBM-SPSS (Chicago, IL, USA). Categorical data were expressed as percentages, while numerical data were given as mean \pm SD and median. Intergroup results were compared via the Chi-square test or the likelihood ratio test. Survival analysis was done with the Kaplan-Meier method, and the log-rank test to assess the survival difference. A correlation between overall survival and other variables was investigated backwards with the Cox regression analysis: LR method. The $p$-value $<0.05$ was deemed statistically important. 


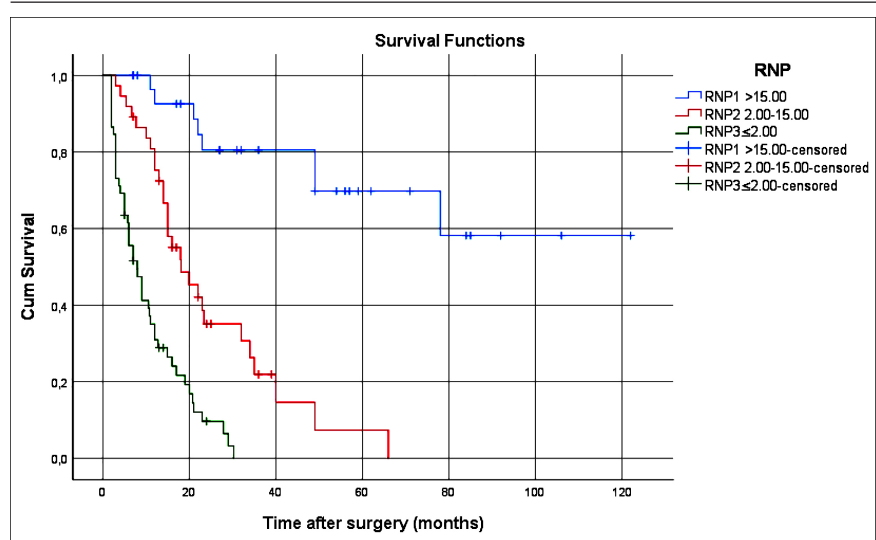

Figure 1: Survival comparison (Kaplan-Meier curves) of the patients according to RNP $(p<0.001)$. RNP: Ratio of negative/positive lymph node.

\section{RESULTS}

The majority of the 119 patients were males $(81.5 \%, \mathrm{n}=$ 97). The median age was 66 years, range $40-88$ years. The mean count of the dissected lymph nodes was $27.3 \pm 11.7$. The average count of negative lymph nodes was $17.6 \pm$ 11.3 , but the average count of positive lymph nodes was 9.7 \pm 9.4 . The study's mean in the following period was $22.1 \pm$ 23.0 months (range: 2 - 122 months). More than two-thirds $(69.7 \%, n=83)$ of patients died during the follow-up period.

The Chi-square distribution of clinicopathological variables with RNP is summarised in Table I. Pathologic $N$ stage ( $p$ $<0.01)$, PNI $(p<0.01), \operatorname{LVI}(p=0.01)$, tumour type $(p$ $<0.01)$, grade $(p<0.01)$, number of negative lymph nodes $(p<0.01)$ and RNP ( $p<0.01$ ) in univariate analysis, as well as total overall survival, were strongly significant and maintained for gender $(p=0.025)$, gastrectomy type $(p=$ $0.037)$, PNI ( $p=0.028)$, tumour type $(p=0.006)$, and count of negative lymph nodes $(p=0.003)$ in multivariate analyses (Table II).

The RNP was an independent prognostic criterion for overall survival ( $p=0.003$, Table II). Advanced pathologic T and $\mathrm{N}$ stages, presence of $\mathrm{PNI}$, presence of $\mathrm{LVI}$, high tumour grade and diffuse-type as per Lauren's classification, and count of the negative lymph nodes and RNP were also significantly associated with poor survival ( $p<0.001$ ) (Figure 1 ).

\section{DISCUSSION}

This retrospective study showed that RNP is an adverse prognostic factor for survival with gastric adenocarcinoma, or those who underwent curative gastrectomy with D2 lymph node dissection. The RNP value as an independent prognostic factor is shown in other studies. ${ }^{3,4,9}$

Many studies have shown that the count of negative lymph nodes has a significant impact on the survival of gastric cancer patients as an alternative to the $\mathrm{pN}$ stage. ${ }^{3,10-12}$ However, this is primarly determined by the extent of lymphadenectomy. Occult lymph node metastasis was asso- ciated with shorter survival in patients with N0 gastric carcinoma, and it has been claimed that D2 lymph node dissection may be effective in improving prognosis. ${ }^{4,10}$ The present findings support this hypothesis, considering that the patients underwent curative gastrectomy with lymphadenectomy D2. As such, the count of negative lymph nodes was demonstrated to play a role in defence against invasion and metastasis of cancer cells. ${ }^{13,14}$ Adequate lymph node sampling via curative lymph node dissection contributed to local control of the disease by removing isolated tumour cells and micrometastatic foci. ${ }^{9}$ D2 lymph node resection enabled histopathological evaluation of more lymph nodes, with an increased count of dissected nodes, approximating the stage migration effect. ${ }^{15}$ Metastatic node count is correlated to cumulative count of dissected lymph nodes. ${ }^{8}$ Negative node count (>15) was an independent prognostic factor in univariate and multivariate analyses. D2 lymph node resection, with curative gastrectomy, accurately represents lymph node involvement in gastric cancer.

The AJCC staging manual recommends sampling and histopathological evaluation of 16 regional nodes, but does not provide suggestions regarding extent of lymph node dissection, which represents a shortfall of the AJCC system. ${ }^{5}$ In this series, the pN stage was not an independent factor in multivariate analysis, but was associated with survival in the univariate analysis. However, while pN1 stage has been effective as a prognostic factor in multivariate analysis, it was observed how there was no independent prognostic factor in advanced stage $\mathrm{pN}$. Despite this, the authors showed that all 3 subtypes of RNP are independent prognostic factors in multivariate analysis. Other studies support the findings of the present study. Lin et al. conducted a study on independent prognostic factors in gastric cancer patients, undergoing curative resection, and found that the $\mathrm{pN}$ stage was an independent prognostic factor in one way variance analysis, but failed to confirm this finding in multivariate analysis. ${ }^{16}$ Lee et al. states that $\mathrm{pN}$ is not an independent prognostic marker of gastric cancer. ${ }^{17}$ In another study on the prognostic effect of the count of dissected lymph nodes, the pN stage was not found to be an independent marker. ${ }^{9}$

Epithelial tumours usually metastasise via lymphovascular channels and/or via nerves, (PNI). Although PNI was found to relate to survival in univariate and multivariate analyses, LVI was an independent prognostic marker despite its significant effect on survival in the univariate analysis. Prognostic importance of (PNI) in gastric cancer is controversial. While some authors report that PNI is not a prognostic marker, De Franco et al. report it is associated with advanced stage and poor long-term survival, and may act as an adjunctive marker in the intestinal tract's histotype. ${ }^{18,19}$ These findings support that PNI is an independent prognostic marker in gastric cancer patients who undergo curative gastrectomy. The authors think the prognostic role of LVI must be investigated in larger groups or by meta-analysis, with conflicting evidence on the prognostic value of LVI, including the results 
of this study. ${ }^{4,20}$

Another parameter found to be an independent prognostic marker was histologic tumour type. Diffuse type gastric cancer had a significantly shorter survival. While some studies support our finding, others could not confirm the prognostic value of histologic type in gastric cancer., ${ }^{4,21,22}$

The present authors could not prove the prognostic effect of histologic grade in multivariate analysis, although it was significantly associated with survival in one way variance analysis. Prognostic effect of the histologic grade of gastric carcinoma remains controversial; thus, further investigation is required to demonstrate it is actually an independent prognostic factor. ${ }^{23,24}$

The present study has some limitations. First, there is no standard cut-off value to determine RNP, as the authors used the cut-off in the Yamashita et al. study. ${ }^{4,25}$ A standard cut-off value should be identified to use RNP as an independent prognostic factor vs. the $\mathrm{pN}$ stage in gastric cancer patients. The second limitation is the study group size; with more precise results obtained with more patients.

\section{CONCLUSION}

RNP can be an alternative, independent prognostic marker for gastric cancer, a new alternative indicator for prognosis assessment following curative gastrectomy and enhancing the current TNM staging system.

\section{ETHICAL APPROVAL:}

This study was approved by The Ethics Committee of Cumhuriyet University, Sivas, Turkey (Reference No: 2009-12/25, 11/12/2009).

\section{PATIENTS' CONSENT:}

Data of this retrospective research was obtained from the clinical archive.

\section{CONFLICT OF INTEREST:}

The authors declared no conflict of interest.

\section{AUTHORS' CONTRIBUTION:}

HA: Conception and design, discussion and literature review.

MK: Acquisition of data, interpretation of data.

MCM: Acquisition of data, search of the literature.

MG: Search of the literature, drafting of manuscript.

HÖ: Analysis and interpretation of data.

KK: Critical revision of the manuscript.

\section{REFERENCES}

1. Zhang XY, Zhang PY. Gastric cancer: Somatic genetics as a guide to therapy. J Med Genetics 2017; 54(5):305-12. doi: 10.1136/jmedgenet-2016-104171.

2. Bray F, Ferlay J, Soerjomataram I, Siegel R, Torre L, Jemal A. Erratum: Global cancer statistics 2018: GLOBOCAN estimates of incidence and mortality worldwide for 36 cancers in 185 countries. CA Cancer J Clin 2020; 70(4):313. doi: 10.3322/caac.21609.

3. Hou $Y$, Wang $X$, Chen J. Prognostic significance of metastatic lymph node ratio: The lymph node ratio could be a prognostic indicator for patients with gastric cancer. World J Surg Oncol 2018; 16(1):1-9. doi: 10.1186/s12957018-1504-5.

4. Yamashita K, Hosoda K, Ema A, Watanabe M. Lymph node ratio as a novel and simple prognostic factor in advanced gastric cancer. Eur J Surg Oncol 2016; 42(9):1253-60. doi: 10.1016/j.ejso.2016.03.001.

5. In H, Solsky I, Palis B, Langdon-Embry M, Ajani J, Sano T. Validation of the 8th edition of the AJCC TNM staging system for gastric cancer using the national cancer database. Ann Surg Oncol 2017; 24(12):3683-91. doi: 10.1245/s10434017-6078-x.

6. Gu P, Deng J, Wang W, Wang Z, Zhou Z, Xu H, et al. Impact of the number of examined lymph nodes on stage migration in node-negative gastric cancer patients: A Chinese multi-institutional analysis with propensity score matching. Ann Transl Med 2020; 8(15):938. doi: 10.21037/atm-19-4727.

7. Deng J, Liu J, Wang W, Sun Z, Wang Z, Zhou Z, et al. Validation of clinical significance of examined lymph node count for accurate prognostic evaluation of gastric cancer for the eighth edition of the American joint committee on cancer (AJCC) TNM staging system. Chinese J Cancer Res 2018; 30(5):477. doi: 10.21147/j.issn.1000-9604.2018. 05.01.

8. Supsamutchai C, Wilasrusmee C, Jirasiritham J, Rakchob T, Phosuwan S, Chatmongkonwat $\mathrm{T}$, et al. Recurrence outcome of lymph node ratio in gastric cancer after underwent curative resection: A retrospective cohort study. Annals Med Surg 2020; 54:57-61. doi: 10.1016/j.amsu.2020.04.002.

9. Deng J, Zhang R, Wu L, Zhang L, Wang X, Liu Y, et al. Superiority of the ratio between negative and positive lymph nodes for predicting the prognosis for patients with gastric cancer. Ann Surg Oncol 2015; 22(4):1258-66. doi: 10.1245/s10434-014-4121-8.

10. Zhang N, Deng J, Wang W, Sun Z, Wang Z, Xu H, et al. Negative lymph node count as an independent prognostic factor in stage III patients after curative gastrectomy: A retrospective cohort study based on a multicenter database. Int J Surg 2020; 74:44-52. doi: 10.1016/j.ijsu. 2019.12.018.

11. Tez M, Altundag K. Log odds of metastatic lymph nodes (LODDS) or negative to positive lymph node ratio? Surgery 2017; 162(2):461. doi: 10.1016/j.surg.2017.01.021.

12. Hayashi S, Kanda M, Ito S, Mochizuki $Y$, Teramoto $H$, Ishigure $\mathrm{K}$, et al. Number of retrieved lymph nodes is an independent prognostic factor after total gastrectomy for patients with stage III gastric cancer: Propensity score matching analysis of a multi-institution dataset. Gastric Cancer 2019; 22(4):853-63. doi: 10.1007/s10120-0180902-2.

13. Ogawa S, Itabashi M, Bamba $Y$, Yamamoto $M$, Sugihara $K$. Superior prognosis stratification for stage III colon cancer using log odds of positive lymph nodes (LODDS) compared to TNM stage classification: The Japanese study group for postoperative follow-up of colorectal cancer. Oncotarget 2020; 11(33):3144. doi: 10.18632/oncotarget.27692.

14. Zhang QW, Zhang $\mathrm{CH}$, Pan YB, Biondi A, Fico V, Persiani R, 
et al. Prognosis of colorectal cancer patients is associated with the novel log odds of positive lymph nodes scheme: Derivation and external validation. J Cancer 2020; 11(7):1702. doi: 10.7150/jca.38180.

15. Deng J, You Q, Gao Y, Yu Q, Zhao P, Zheng Y, et al. Prognostic value of perineural invasion in gastric cancer: A systematic review and meta-analysis. PLoS One 2014; 9(2):e88907. doi: 10.1371/journal.pone.0088907.

16. Lin D, Li Y, Xu H, Chen J, Wang B, Liu C, et al. Lymph node ratio is an independent prognostic factor in gastric cancer after curative resection (R0) regardless of the examined number of lymph nodes. Am J Clin Oncol 2013; 36(4):325-30. doi: 10.1097/COC.0b013e318246b4e9.

17. Lee SR, Kim HO, Son BH, Shin JH, Yoo CH. Prognostic significance of the metastatic lymph node ratio in patients with gastric cancer. World J Surg 2012; 36(5):1096-101. doi: 10.1007/s00268-012-1520-5.

18. Liebig C, Ayala G, Wilks JA, Berger DH, Albo D. Perineural invasion in cancer: A review of the literature. Cancer: Interdisciplinary. Int J Am Cancer Society 2009; 115(15): 3379-91.

19. De Franco L, Marrelli D, Voglino C, Vindigni C, Ferrara F, Di Mare $G$, et al. Prognostic value of perineural invasion in resected gastric cancer patients according to Lauren histotype. Pathol Oncol Res 2018; 24(2):393-400. doi: 10.1007/s12253-017-0257-8.
20. Fujikawa H, Koumori K, Watanabe H, Kano K, Shimoda $Y$, Aoyama $T$, et al. The clinical significance of lymphovascular invasion in gastric cancer. In Vivo. 2020; 34(3):1533-9. doi: 10.21873/invivo.11942.

21. Zhang M, Wang J, Shi W, Chen W, Li W, Shu Y, et al. Prognostic significance of metastatic lymph nodes ratio in patients with gastric adenocarcinoma after curative gastrectomy. Chinese Med J 2014; 127(10):1874-8.

22. Waldum HL, Fossmark R. Types of gastric carcinomas. Int J Molecular Sci 2018; 19(12):4109. doi: 10.3390/ijms 19124109.

23. Zhang BY, Yuan J, Cui ZS, Li ZW, Li XH, Lu YY. Evaluation of the prognostic value of the metastatic lymph node ratio for gastric cancer. Am J Surg 2014; 207(4):555-65. doi: 10.1016/j.amjsurg.2013.05.004.

24. Xiao LB, Yu JX, Wu WH, Xu FF, Yang SB. Superiority of metastatic lymph node ratio to the 7 th edition UICC N staging in gastric cancer. World J Gastroenterol WJG. 2011; 17(46):5123. doi: 10.3748/wjg.v17.i46.5123.

25. Deng J, Liang $H$, Wang $D$, Sun $D$, Ding $X$, Pan $Y$, et al. Enhancement the prediction of postoperative survival in gastric cancer by combining the negative lymph node count with ratio between positive and examined lymph nodes. Ann Surg Oncol 2010; 17(4):1043-51. doi: 10.1245/ s10434-009-0863-0. 